\title{
НЕЧІТКА МОДЕЛЬ УПРАВЛІННЯ ТЕМПЕРАТУРОЮ ПРЕС-ФОРМИ
}

\begin{abstract}
Анотація: Процес лиття під тиском (ЛПТ) - найбільш перспективний спосіб виробництва виливків, що піддається автоматизації, так як все технологічне устаткування повністю механізоване й підготовлене для функціонування у складі АСК ТП. Головною метою роботи на сьогоднішній день $€$ підвищення ефективності керування процесом ЛПТ шляхом удосконалення й впровадження системи управління, в основі якої лежать моделі нечіткої логіки, з автоматичним вибором структури математичної моделі й самонастроювання її параметрів для безперервного функціонування в режимі керування. Автоматична система керування (АСК) забезпечує нормальну роботу комплексів ЛПТ при мінімальній собівартості продукції, підвищує якість і розширює сортамент відливок, що виплавляються.
\end{abstract}

Ключові слова: нечітка логіка, система регулювання, лиття під тиском.

\section{Вступ}

В теперішній час лиття під тиском (ЛПТ) е одним з найбільш розповсюджених спеціальних способів виготовлення високоточних відливок із кольорових сплавів на основі алюмінію, міді, цинку, магнію. Основний недолік ЛПТ - висока собівартість відливок, яка в значному ступені (до $75 \%$ ) визначається витратами на проектування і виготовлення прес-фрорм, а також їх експлуатаційною стійкістю. Остання в значній мірі залежить від кількості теплозмін і теплових ударів [1]. Зменшення кількості цих небажаних явищ досягають регулюванням температури прес-фрорми. У практиці ЛПТ для попереднього розігріву прес-фрорми використовують газові пальники й електронагрівачі. В останній час з цією метою все ширше використовують установки для підігріву і охолодження форми рідкими теплоносіями [2]. Найбільш важливий вузол - термостат, що зв'язаний з каналами нагріву-охолодження прес-форм гнучкими з'єднувальними рукавами. При використанні термостатів на перший план висуваеться точність регулювання температури рідкого теплоносія [3]. При цьому використання типових ПІД-регуляторів не призводить до позитивного ефекту.

Наведені в статті дослідження проводились в Національному технічному університеті України “КПІ” по темі “Система керування машини лиття під тиском на основі нечіткої логіки”, державний реєстраційний номер 0114U002566.

\section{Постановка задачі}

Метою досліджень є підвищення точності термостатування прес-форми.

(c) В.С. Богушевський, Р.В. Самарай, В.П. Самарай, 2015 


\section{Результати досліджень}

Дослідження проводились на термостаті, що представляе собою теплоізольований, заповнений теплоносіем бак.

Теплообмінник є типовим об'ектом управління з запізнюванням. Останне значно зменшуе швидкодію системи і динамічну точність об'екта управління.

Передаточна функція такого об'єкта $W_{o}(s)=e^{-s T} G(s)$, де $G(s)$ - передаточна функція об'екта без запізнення. Найбільш ефективним методом боротьби з запізненням є охвачування регулятора $\mathrm{P}$ ланкою зворотного зв'язку з передаточною функцією $W_{o c}(s)=\left(1-e^{-s T}\right) G(s)$, яку називають предиктором (випереджувачем) Сміта. Структурні схеми систем автоматичного управління з предиктором Сміта наведені на рис. 1 а,б. Предиктор Сміта може бути включений також паралельно об'екту управління, як показано на рис. 1в,г [4].

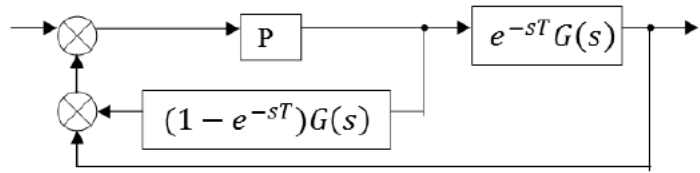

a

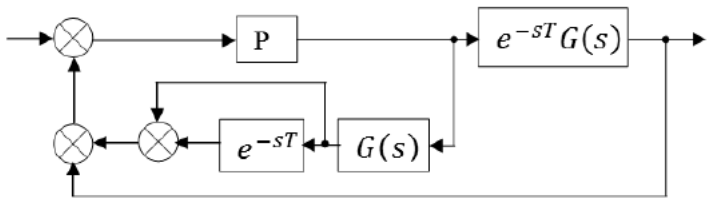

б

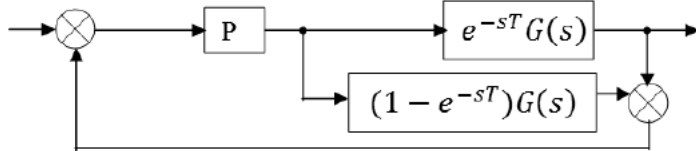

B

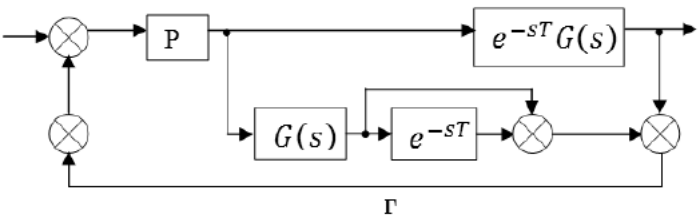

Рис. 1 - Структурні схеми систем автоматичного управління з предиктором Сміта

Для всіх схем передаточна функція замкнутої системи управління $W_{3}(s)$ має вигляд 


$$
W_{3}(s)=\frac{W_{p}(s) G(s)}{1+W_{p}(s) G(s)} e^{-s T},
$$

де $W_{p}(s)$ - передаточна фрункція регулятора.

Якщо синтезувати регулятор для об’єкта без запізнювання $G(s)$, то при наявності запізнення якість перехідного процесу не змінеться, а відбувається лише зміщення вихідної змінної системи на час запізнення $T$. Ланку запізнення з передаточною функцією $e^{-s T}$ при моделюванні реалізуємо наближенням Паде першого порядку

$$
e^{-s T} \approx \frac{2-T s}{2+T s}
$$

або наближенням Паде другого порядку

$$
e^{-s T} \approx \frac{12-6 T s+T^{2} s^{2}}{12+6 T s+T^{2} s^{2}} .
$$

Вибір вхідних та вихідних параметрів процесу з побудовою функцій приналежності

При проектуванні системи управління з оптимальним за швидкодією цифровим регулятором і об’єктом управління з чистим запізненням так, щоб система “апроксимувала" довільне вхідне діяння сигналом, який лінійно змінюеться на інтервалах регулювання, необхідно визначати оптимальні керуючі діяння на об'єкт управління. Ці діяння на об'єкт управління з передаточною фрункцією $e^{-s T} G(s)$ можна знайти модифікуючи фрормули, що отримані в роботах [5-7], для оптимальних керуючих діянь на об'єкт управління з передаточною функцією $G(s)$ наступним чином:

1. Інтервал регулювання визначити як $t_{p}=N h+\tau$, де $N$ - порядок передаточної фрунції об'єкта управління, $h$ - крок квантування у цифровому регуляторі, $T \equiv \tau-$ час запізнення.

2. Оскільки за час запізнення помилка змінюеться на величину $\tau \Delta \sigma$, то замість помилки системи $\theta_{n}$ в момент початку $n$-го інтервалу регулювання (в момент $n t_{p}$ ) у формули необхідно підставити $\theta_{n}+\tau \Delta \sigma$, де $\Delta \sigma=\sigma_{n}-\sigma_{n-1}$, тут $\sigma_{n}-$ перша різниця вхідного діяння на $n$-му інтервалі регулювання $n t_{p} \leq t \leq(n+1) t_{p}, \sigma_{n-1}-$ перша різниця вхідного діяння на $(n-1)$-му інтервалі регулювання $(n-1) t_{p} \leq t \leq n t_{p}$.

Наприклад, на вхід об'єкта управління, математична модель якого описується передаточною фукцією $G(s)=\alpha[s(s+a)(s+b)]^{-1}$ на $n$-му інтервалі регулювання $n t_{p} \leq t \leq(n+1) t_{p}$ необхідно подавати діяння: 


$$
\left\{\begin{aligned}
m_{0}= & K_{0}\left(\Delta U+S_{0} \Delta \sigma\right)+R \sigma_{n-1} ; n t_{p} \leq t \leq n t_{p}+h \\
m_{1}= & K_{0}\left[q_{1}\left(\Delta U+S_{0} \Delta \sigma\right)+h \Delta \sigma\right]+R \sigma_{n-1} ; n t_{p}+h \leq t \leq n t_{p}+2 h \\
m_{2}= & K_{0}\left[q_{2}\left(\Delta U+S_{0} \Delta \sigma\right)+h \Delta \sigma\left(1+q_{1}\right)\right]+R \sigma_{n-1} \\
& n t_{p}+2 h \leq t \leq n t_{p}+3 h
\end{aligned}\right.
$$

де $K_{0}=\frac{a b}{\alpha h(1-A)(1-B)} ; S_{0}=3 h+\frac{a+b}{a b}-\frac{h\left(2+q_{1}\right)}{(1-A)(1-B)} ; R=\frac{a b}{\alpha} ; q_{1}=$ $-(A+B) ; q_{2}=A B ; A=e^{-a h} ; B=e^{-b h} . \Delta U=\theta_{n}$.

Тут $\theta_{n}$ - помилка системи в момент $n$-го інтервала регулювання, тобто помилка системи в момент $n t_{p}$. Інтервал регулювання $t_{p}=N h=3 h N=3$ - порядок об'єкта; $h$ - крок квантування; на $(n-1)$-му інтервалі регулювання $(n-1) t_{p} \leq t \leq b t_{p}$ вхідне діяння характеризуеться першою різницею $\sigma_{n-1}$, на $n$-му інтервалі регулювання $n t_{p} \leq t \leq(n+1) t_{p}$ - першою різницею $\sigma_{n} ; \Delta \sigma=\sigma_{n}-\sigma_{n-1}$, $n=0,1,2, \ldots$

Підкреслимо, що $m_{0}, m_{1}, m_{2}$ - прямокутні керуючі імпульси, кожний з яких має тривалість $h$ і відповідну амплітуду. Якщо число імпульсів $N$, де $N$ - порядок об’єкта, то інтервал регулювання $t_{p}=N h$.

На вхід об'єкта керування з передаточною фрункцією $G(s)=$ $\alpha e^{-\tau s}[s(s+a)(s+b)]^{-1}$ необхідно, починаючи з момента $n t_{p}$, подавати діяння:

$$
\left\{\begin{aligned}
m_{0}= & K_{0}\left(\Delta U+\tau \Delta \sigma+S_{0} \Delta \sigma\right)+R \sigma_{n-1} ; n t_{p} \leqslant t \leqslant n t_{p}+h \\
m_{1}= & K_{0}\left[q_{1}\left(\Delta U+\tau \Delta \sigma+S_{0} \Delta \sigma\right)+h \Delta \sigma\right]+R \sigma_{n-1} \\
& n t_{p}+h \leqslant t \leqslant n t_{p}+2 h \\
m_{2}= & K_{0}\left[q_{2}\left(\Delta U+\tau \Delta \sigma+S_{0} \Delta \sigma\right)+h \Delta \sigma\left(1+q_{1}\right]+R \sigma_{n-1}\right. \\
& n t_{p}+2 h \leqslant t \leqslant n t_{p}+3 h
\end{aligned}\right.
$$

а також $m_{3}=R \sigma_{n-1}$, якщо $n t_{p}+3 h \leq t \leq n t_{p}+3 h+\tau$.

Порівнюючи вирази (4) і (5) відмітимо, що для об'єкта із запізнюванням можна використовувати формули (4) замість формул (5) для керуючих імпульсів, але для цього необхідно у формулах (4) величину $S_{0}$ замінити новим значенням $S_{0}^{*}=S_{0}+\tau$ :

$$
S_{0}^{*}=3 h+\frac{a+b}{a b}-\frac{h\left(2+q_{1}\right)}{(1-A)(1-B)}+\tau .
$$

При розрахунках можна час запізнювання $\tau$ (особливо при великому запізнюванні) виражати через ціле число кроків квантування $\tau=L h$. Тоді інтервал регулювання можна визначити як $t_{p}=(N+L) h$. При цьому у кожному інтервалі регулювання після $N$ прямокутних керуючих імпульсів проходить $L$ прямокутних імпульсів однакової амплітуди $R \sigma_{n-1}$.

Якщо $\tau$ менше $h$, то зручно крок квантування $h$ виражати через ціле число інтервалів запізнювання $\tau: h=M \tau$. Тоді інтервал регулювання можна визначити як $t_{p}=N h+\tau=(N M+1) \tau$. 
Застосовуемо стандартну схему системи керування з нечітким регулятором (НР) [8] (рис. 2).

НР реалізуеться на мікропроцесорі, й працюе у дискретному режимі. Тому система автоматичного керування з НР вміщуе пристрої зв'язку з об'єктом - АЦП і ЦАП. АЦП квантує неперервну помилку $\theta(t)=u(t)-x(t)$ з кроком квантування $h$. $\mathrm{B}$ якості першої $\mathrm{i}$ другої похідної обчислювали першу і другу різницю за формулами

$$
\begin{gathered}
\theta(k)=[\theta(k)-\theta(k-1)] / h ; \\
\theta(k)=[\theta(k)-\theta(k-1)] / h=\left[\theta(k)-2 \theta(k-1) / h^{2},\right.
\end{gathered}
$$

де $\theta(k)$ - квантована помилка на виході АЦП.

ЦАП представляе собою фіксатор нульового порядку з передаточною функцією $W(s)=\left(1-e^{-h s}\right) / s$.

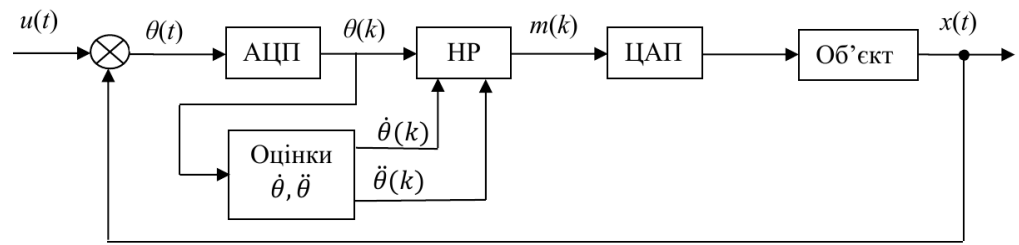

Рис. 2 - Схема керування з цифровим регулятором: АЦП -аналого-цифровой перетворювач; ЦАП -- цифро-аналоговий перетворювач

При вирішенні задачі синтезу нечіткого регулятора приймаємо число термів, з допомогою якого оцінюють лінгвістичні змінні (вхідні й вихідний параметр НР) помилки системи в регулюрованні температури $\theta$, швидкість зміни (перша похідна) помилки $\dot{\theta}$, прискорення (друга похідна) помилки $\ddot{\theta}$, керуюче діяння на об'єкт $m$, таким, що дорівнюе 3 . Установимо діапазони зміни лінгвістичних змінних рівними $\left[\theta_{\min }, \theta_{\max }\right],\left[\dot{\theta}_{\min }, \dot{\theta}_{\max }\right],\left[\ddot{\theta}_{\min }, \ddot{\theta}_{\max }\right], \mathrm{i}\left[m_{\min }, m_{\max }\right]$ Перерахунок значень кожної лінгвістичної змінної $x_{i}, i=1, n, n=4$, у відповідний елемент керування $u^{*} \in[0,1]$ визначається виразом

$$
u_{i}^{*}=\left(x_{i}-x_{H i}\right) /\left(x_{B i}-x_{H i}\right),
$$

на основі якого знаходимо:

$$
\begin{aligned}
& \left\{\begin{array}{l}
u_{1}^{*}=\left(\Theta-\Theta_{\min }\right) /\left(\Theta_{\max }-\Theta_{\min }\right) ; \\
u_{2}^{*}=\left(\Theta-\Theta_{\min }\right) /\left(\Theta_{\max }-\Theta_{\min }\right) ; \\
u_{3}^{*}=\left(\Theta-\Theta_{\min }\right) /\left(\Theta_{\max }-\Theta_{\min }\right) ;
\end{array}\right. \\
& u_{c}^{*}=\left(m-m_{\min }\right) /\left(m_{\max }-m_{\min }\right) .
\end{aligned}
$$


При завданні функцій приналежності (ФП) трикутної форми на единій універсальній множині $u=[0,1]$ отримуемо наступні аналітичні вирази для кожної лінгвістичної величини:

$$
\begin{aligned}
& \mu_{1}(u)=1-u, u \in[0, u] ; \mu_{2}=u, u \in[0,1] ; \\
& \mu_{3}(u)= \begin{cases}2 u, & u \in[0,1 / 2] ; \\
2(1-u), & u \in[1 / 2,1]\end{cases}
\end{aligned}
$$

При поданні на НР значень вхідних змінних $\theta, \dot{\theta}, \ddot{\theta}$ з кроком квантування $h$ виконуеться розрахунок величин $u_{1}, u_{2}$ i $u_{3}$ по форомулам (11) і ФП $\mu^{j}(u), j=\overline{1,3}$, по формулам (13).

Лінгвістичне правило управління представляемо у вигляді:

$$
\text { якщо }\left(\theta^{*}=a_{1}^{j}\right) \text { i }\left(\dot{\theta}^{*}=a_{2}^{j}\right) \text { i }\left(\ddot{\theta}^{*}=a_{3}^{j}\right) \text {, то }\left(m^{*}=a_{c}^{j}\right), j=\overline{1,3} \text {, }
$$

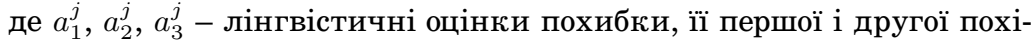
дної, що розглядаємо як нечіткі множини, які визначені на універсальній множині, $j=\overline{1,3}$;

$a_{c}^{j}-$ лінгвістичні оцінки керуючого діяння на об'єкт, що обираються із терм-множини змінної $m$. Лінгвістичні оцінки обираються із терм-множини лінгвістичних змінних $\theta, \dot{\theta}, \ddot{\theta}$ і $m: a_{c}^{j} \in[$ від'емна $(j=1)$, додатна $(j=2)$, наближена до нуля - нульова $(j=3)]$.

При попаданні рідкого металу в ливарну форму остання нагрівається, причому товщина шару від робочої поверхні форми, в якому виникає значний температурний градієнт становить біля 30 мм [9]. Середню температуру приграничного шару контролюють 3 допомогою термопари, гарячий спай якої установлюють на глибині, що дорівнюе половині приграничного шару. Таким чином, можна вважати, що надлишкова ентальпія ливарної форми внаслідок нагріву відливкою зосереджена в деякій приведеній масі $m_{\phi}^{n p}$, кг, що дорівнюе

$$
m_{\phi}^{n p}=K m_{\phi},
$$

де $K$ - коефріціент пропорційності, що залежить від маси фрорми і дорівнюе $0.10-0.14$;

$m_{\phi}$ - маса ливарної форми, кг.

Надлишкову ентальпію ливарної форми можна виразити як

$$
\Delta Q=c_{\phi} m_{\phi}^{n p}\left(t_{\phi}-t_{3}\right)
$$

де $\Delta Q$ - надлишкова ентальпія ливарної форми, Дж;

$c_{\phi p}$ - середня питома теплоємність ливарної форми, Дж/(кг $\left.{ }^{\cdot 0} C\right)$;

$t_{\phi}$ - температура ливарної форми по показанням термопари в момент вилучення відливки, ${ }^{0} \mathrm{C}$;

$t_{3}$ - задана температура ливарної форми, ${ }^{0} \mathrm{C}$. 
Для робочого діапазону температур $\left(150-300^{\circ} \mathrm{C}\right)$ середня питома теплоємність ливарної форми становить 500 Дж/(кг $\left.{ }^{\cdot 0} C\right)$.

Надлишкова ентальпія ливарної форми компенсуеться охолодженням з допомогою теплоносія і теплових втрат у навколишне середовище відповідно виразу

$$
\Delta Q=\int_{(\tau)} c_{m}\left(t_{2}-t_{1}\right) V_{m} d \tau+q \tau_{u},
$$

де $c_{m}$ - середня питома теплоємність теплоносія, Дж/(к $\left.{ }^{\cdot 0} C\right)$;

$t_{2}$ i $t_{1}$ - температура теплоносія відповідно на виході й вході порожнини теплообміника ливарної форми, ${ }^{0} C$;

$\tau-$ поточний час, с;

$q$ - тепловой потік в навколишнє середовище, що залежить від конструкції ливарної форми і дорівнюе $10-20$ кВт;

$\tau_{u}$ - тривалість циклу виготовлення відливки, с.

Середня питома теплоємність теплоносія може бути визначена як

$$
c_{m}=\left(c_{0}\left[1+0,5 \alpha\left(t_{1}+t_{2}\right)\right],\right.
$$

де $c_{0}$ - питома теплоємність теплоносія при $0^{0} C$, Дж $/\left(\kappa \Gamma^{\circ} C\right)$;

$\alpha$ - температурний коефіцієнт, ${ }^{0} C^{-1}$.

При використанні у якості теплоносія мастила значення $c_{0}=$ 1785 Дж/(кг.0 $C)$ i $\alpha=0.74 \cdot 10^{-3} 0 C^{-1}$.

Із співвідношень (16) - (18) отримуемо

$$
c_{\phi} m_{\phi}^{n p}\left(t_{\phi}-t_{3}\right)-q \tau_{u}=\int_{(\tau)} c_{0}\left[1+0,5 \alpha\left(t_{1}+t_{2}\right)\right]\left(t_{2}-t_{1}\right) V_{m} d \tau .
$$

Рівність правої й лівої частин виразу (19) визначається тривалістю подачі теплоносія. Таким чином, подачу теплоносія необхідно припинити в момент досягнення рівності виразу (19).

Вираз (19) також використовуеться для регулювання тривалості подачі теплоносія для нагрівання ливарної форми. В цьому випадку обидві частини виразу (19) будуть менше нуля.

Замкнута система автоматичного управління “регулятор + об'єкт управління" має вигляд (рис. 3). Синтез НР виконано по формулам (4) - (13) для трикутних функцій приналежності з кроком квантування $h=0.1$ с. Помилка на виході АЦП $\theta(k)$, iї перша $\dot{\theta}(k)=[\theta(k)-\theta(k-1)] / h$ і друга $\ddot{\theta}(k)=[\theta(k)-\theta(k-1)] / h$ різниця подаються на вхід НР. Сигнал з виходу НР поступае на ЦАП (фіксатор нульового порядку з передаточною функцією $H(s)=$ $\left(1-e^{-h s}\right) / s$ і далі в неперервну частину системи (теплообмінник + прес-форма).

Система регулювання (рис. 3) виконана на стандартних засобах вимірювання і регулюючому мікроконтролері. 
Прес-форма

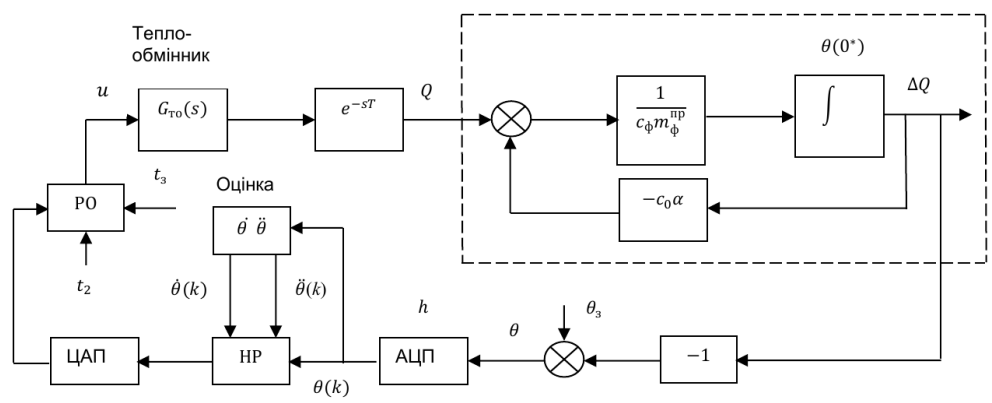

Рис. 3 - Замкнута система автоматичного управління

В якості датчиків температури використані датчики системи Метран-270МП [10], датчиків тиску і витрати - датчики системи Метран-100, датчики вилучення відливки і наявності металу в прес-формі виконані на базі безконтактного датчика положення типу БК. Блоки управління охолодженням і нагрівом представляють собою підсилювачі, що перетворюють одиничний вихідний сигнал контролера в напругу 110 В для включення відповідно електромагнітного клапана магістралі охолоджуючої води і магнітного пускателя, який управляе нагрівом теплоносія.

Регулювання температури прес-форми проводимо за рахунок зміни температури термостатуючої рідини. Тому за вхідні параметри процесу обрано - температуру термостатуючої рідини і пресформи, відхилення температури прес-форми від заданного значення, (помилка регулювання), швидкість та прискорення зміни відхилення та задане значення температури термостатуючої рідини.

Поточне значення температури прес-форми, термостатуючої рідини на вході й виході порожнини теплообміника ливарної форми вимірюеться термопарами.

Значення кожного параметру розділені на терм-множини (табл. 1) та обрані відповідні діапазони зміни для кожного терму.

Як було відмічено ФП мають різний вигляд. Для того, щоб визначити який вид ФП найбільше підходить для побудови нечіткої моделі регулювання температури термостатуючої рідини, розглянемо декілька їх видів, такі як: а) у вигляді рівнобедреного трикутника, б) гаусові, в) трикутні, що перетинають весь діапазон зміни значень параметру.

На рис. 4 (а, б, в) відповідно зображені функції приналежності з різними термами по температурі термостатуючої рідини $\left(t_{p}\right)$, по температурі прес-форми, ${ }^{0} \mathrm{C}\left(t_{\phi}=\gamma\right)$, а також по швидкості $(S)$ та прискоренню зміни зміни температури прес-фрорми $(a)$. 
Вхідні та вихідні параметри, чіткі та лінгвістичні змінні, та інтервали зміни

\begin{tabular}{|c|c|c|c|c|c|c|}
\hline $\begin{array}{l}\text { Вхідні/вихідні } \\
\text { параметри }\end{array}$ & $\begin{array}{l}\text { Сим } \\
\text { вол }\end{array}$ & $\begin{array}{l}\text { Чіткі та } \\
\text { зміни }\end{array}$ & \multicolumn{4}{|c|}{ лінгвістичні змінні, та інтервали } \\
\hline $\begin{array}{l}\text { Температура } \\
\text { прес-фрорми, } \\
{ }^{0} C\end{array}$ & $t_{\phi p}$ & $\begin{array}{l}\text { Набагато } \\
\text { нижча } \\
\text { заданої } \\
\mathrm{K} \\
155- \\
180^{0} \mathrm{C}\end{array}$ & $\begin{array}{l}\text { Нижче } \\
\text { заданої } \\
\mathrm{L} \\
180- \\
205^{0} \mathrm{C}\end{array}$ & $\begin{array}{l}\text { Задана } \\
\text { М } \\
205- \\
225^{0} C\end{array}$ & $\begin{array}{l}\text { Вище за- } \\
\text { даної } \\
\text { I } \\
225- \\
250^{0} \mathrm{C}\end{array}$ & $\begin{array}{l}\text { Набагато } \\
\text { вище за- } \\
\text { даної } \\
\mathrm{G} \\
250- \\
275^{0} \mathrm{C}\end{array}$ \\
\hline $\begin{array}{l}\text { Швидкість } \\
\text { зміни тем- } \\
\text { ператури } \\
\text { прес-форми } \\
\left(10^{-2}\right)^{0} \mathrm{C} / \mathrm{c}\end{array}$ & $S$ & $\begin{array}{l}\text { Велика } \\
\text { від'ємна } \\
\mathrm{N} \\
(-5)-(-3)\end{array}$ & $\begin{array}{l}\text { Невелика } \\
\text { від'ємна } \\
\text { Z } \\
(-3)-(-1)\end{array}$ & $\begin{array}{l}\text { Нульова } \\
\text { P } \\
(-1)-(+1)\end{array}$ & $\begin{array}{l}\text { Невелика } \\
\text { додатна } \\
\mathrm{R} \\
(+1)-(+3)\end{array}$ & $\begin{array}{l}\text { Велика } \\
\text { додатна } \\
\mathrm{E} \\
(+3)-(+5)\end{array}$ \\
\hline $\begin{array}{l}\text { Прискорен- } \\
\text { ня, зміни } \\
\text { температури } \\
\text { прес-форми } \\
\left(10^{-3}\right)^{0} \mathrm{C} / \mathrm{c}^{2}\end{array}$ & $a$ & $\begin{array}{l}\text { Від’ємне } \\
\mathrm{n} \\
-4\end{array}$ & $\begin{array}{l}\text { Нульова } \\
\mathrm{p} \\
0\end{array}$ & $\begin{array}{l}\text { Додат- } \\
\text { на } \\
\mathrm{e} \\
+4\end{array}$ & - & - \\
\hline $\begin{array}{l}\text { Задане зна- } \\
\text { чення тем- } \\
\text { ператури } \\
\text { термостату- } \\
\text { ючої рідини, } \\
{ }^{0} \mathrm{C}\end{array}$ & $t_{3}$ & $\begin{array}{l}\text { Низьке } \\
\text { А } \\
145-175\end{array}$ & $\begin{array}{l}\text { Нижче } \\
\text { сере- } \\
\text { днього } \\
\text { В } \\
175-205\end{array}$ & $\begin{array}{l}\text { Hа cepe- } \\
\text { дині } \\
\text { С } \\
205-225\end{array}$ & $\begin{array}{l}\text { Вище } \\
\text { серед- } \\
\text { нього } \\
\text { D } \\
225-255\end{array}$ & $\begin{array}{l}\text { Високе } \\
\text { F } \\
255-285\end{array}$ \\
\hline
\end{tabular}

\section{Формування бази правил систем нечіткого виводу}

Після побудови функцій приналежності, були розроблені нечіткі лінгвістичні правила. Правила розроблялись так: якщо температура прес-фрорми набагато вище заданого значення, а швидкість зміни її від'ємна, а прискорення додатне, то поточне задане значення температури термостатуючої рідини, треба встановити на рівні нижче середнього.

Таким чином розроблено 74 правила, у даному розділі представлено тільки фрагмент.

Правило 1. Якщо температура термостатуючої рідини знаходиться на середньому рівні, температура прес-фроми набагато вище заданого значення, а швидкість зміни їі невелика додатна, а прискорення додатне, то поточне задане значення температури термостатуючої рідини, треба встановити на рівні низьке.

Правило 2. Якщо температура термостатуючої рідини знаходиться на середньому рівні, температура прес-фроми набагато вище заданого значення, а швидкість зміни їі невелика від'ємна, а прискорення додатне, то поточне задане значення температури термостатуючої рідини, треба встановити на рівні нижче середнього. 

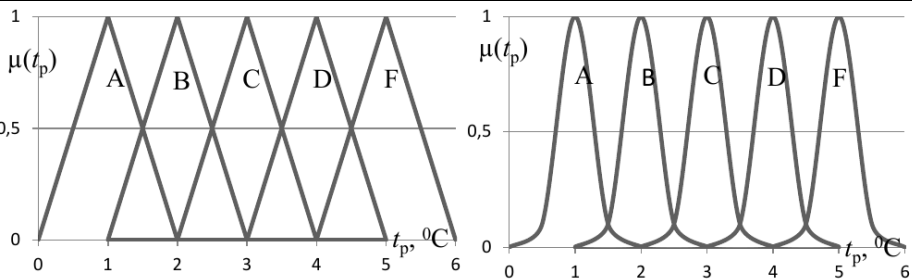

a)

б)

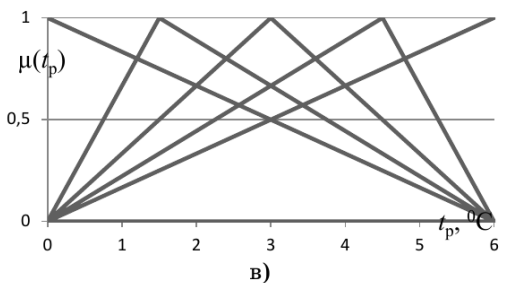

Рис. 4 - Функції приналежності поточного значення температури термостатуючої рідини: а) з трикутними термами; б) з гаусовими термами; в) з трикутними термами, що перетинають весь діапазон

Правило 3. Якщо температура термостатуючої рідини знаходиться на середньому рівні, температура прес-форми вище заданого значення, а швидкість зміни ії невелика від'ємна, а прискорення додатне, то поточне задане значення температури термостатуючої рідини, треба залишити на середньому рівні.

Правило 4. Якщо температура термостатуючої рідини знаходиться на середньому рівні, температура прес-форми вище заданого значення, а швидкість зміни їі велика додатна, а прискорення додатне, то поточне задане значення температури термостатуючої рідини, треба встановити на рівні низьке.

Правило 5. Якщо температура термостатуючої рідини знаходиться на середньому рівні, температура прес-форми відповідає заданому значенню, а швидкість зміни ії велика від'ємна, а прискорення додатне, то поточне задане значення температури термостатуючої рідини, треба встановити на рівні вище середнього.

Для скорочення запису запишемо правила у символічному вигляді (фррагмент):

Правило 1. Якщо $t_{\phi}=G, S=R, a=e$, то $t_{3}=A$.

Правило 2. Якщо $t_{\phi}=G, S=Z, a=e$, то $t_{3}=B$.

Правило 3. Якщо $t_{\phi}=I, S=Z, a=e$, то $t_{3}=C$.

Правило 4. Якщо $t_{\phi}=I, S=E, a=e$, то $t_{3}=A$.

Правило 5. Якщо $t_{\phi}=M, S=N, a=e$, то $t_{3}=D$.

де $t_{p}, t_{3}$ - поточне та задане значення температури термостатуючої рідини, ${ }^{0} C$; 
$\gamma$ - поточне значення температури прес-фрорми, ${ }^{0} C$;

$S$ - швидкість зміни температури прес-фрорми, ${ }^{0} C / c$, яка визначається як: $S=\frac{\gamma_{2}-\gamma_{1}}{\Delta t}$.

Тут $\gamma_{1}, \gamma_{2}$ - попереднє та поточне виміряне значення температури прес-фрорми, ${ }^{0} C ; \Delta \tau-$ різниця часу між двома послідовними вимірами, с;

$a$ - прискорення зміни температури прес-дрорми, ${ }^{0} C / c^{2}$.

Управління з цифровим нечітким регулятором, а також 3 ПІД регулятором

В інтерактивній системі Matlab за допомогою пакету Simulink [11] було складено блок-діаграму системи управління температурою прес-форми. Математична модель управління з НР в інтерактивній системі Matlab складена наступним чином (рис. 5).

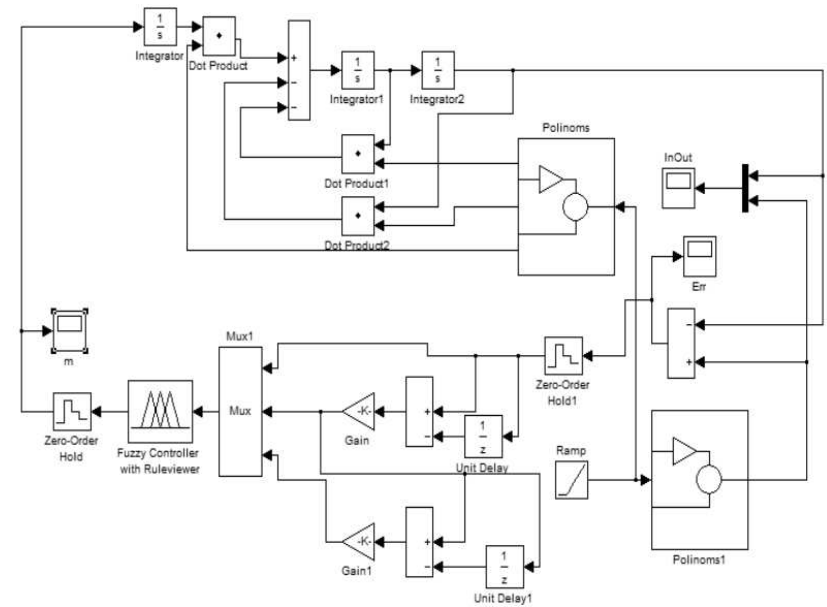

Рис. 5 - Структурна схема системи управління з цифровим нечітким регулятором

Похибка Err, що поступає на вхід регулятора, представляє собою різницю між заданою температурою прес-фрорми - $u(t)$ та отриманою $-x(t): \theta(t)=u(t)-x(t)$.

Зміну заданої температури прес-фрорми із часом задано поліномами у блоці Polinoms1.

Регулювання відбувається таким чином, на вхід моделі поступає сигнал $m(t)$ з виходу блоку Integ rator. Вихідний сигнал об'єкта управління $x(t)$ отримуємо на виході блоку Integ rator 1 . На виході блоку Polinoms фрормуються сигнали коефіцієнтів.

Так, відповідно до складеної системи, зміна коефіцієнта представлена у блоці Fcn5, за допомогою перемикачу Switch3 відбувається переключення сигналу на іншу залежність, яка представле- 
на у блоці Constant2, і далі перемикачем Switch2 зміна коефіціенту виконуеться за залежністю представленою у блоці Fcn4. Аналогічним чином представлені інші коефріціенти.

Сигнали коефіціентів, у відповідних блоках множення Dot Product множаться на вихідний сигнал $m(t)$ відповідно записаному вище диференційному рівнянню нестаціонарної коливальної ланки.

В систему управління входить аналого-цифровий перетворювач АЦП, що представлений фiксатором Zero-Order Hold, який працює з кроком квантування $h_{0}$, і вихідний цифроаналоговий перетворювач, що представлений фіксатором Zero-Order Hold 1.

Регулятор нечіткої логіки представлений блоком Fuzzy Logic Controller with ruleviewer, у даному блоці задаються вхідні та вихідний параметри процесу, обираються функції приналежності membership functions, діапазони зміни значень та задаеться база правил rules.

За вихідні параметри обрано помилку $\theta$, першу $(S)$ та другу (a) похідні від помилки, які реалізують рівняння: $S \approx$ $\{\theta(n)-\theta(n-1)\} / h, a \approx\{s(n)-s(n-1)\} / h$.

Налаштування регулятора виконані з метою отримання найменшої помилки невідповідності.

На рис. 6 зображено фрункцію приналежності по помилці невідповідності, яку розроблено в системі Matlab. Аналогічним чином розроблено функції приналежності для інших вхідних та вихідного параметрів. Час моделювання задано $10 \mathrm{c}$.

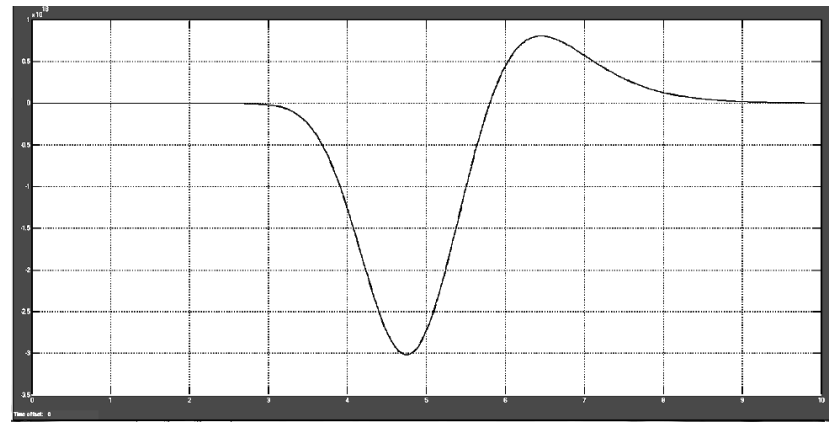

Рис. 6 - Результат розв'язання задачі нечіткого моделювання методом Мамдані, графік похибки Err

\section{Висновки}

В даній схемі були застосовані нечіткі регулятори на основі методів Мамдані та Сугено, а також ПІД регулятора. Усього отримано 3 схеми. Час циклу моделювання становить 10 одиниць (10 секунд 


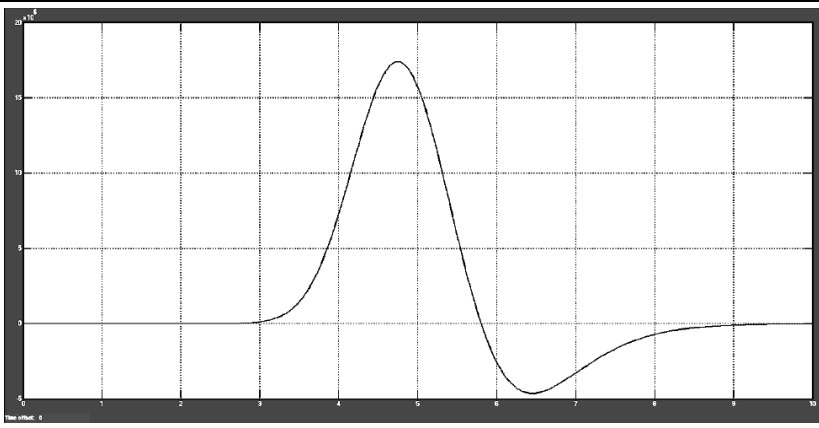

Рис. 7 - Результат розв'язання задачі нечіткого моделювання алгоритмом Сугено, графік похибки Err

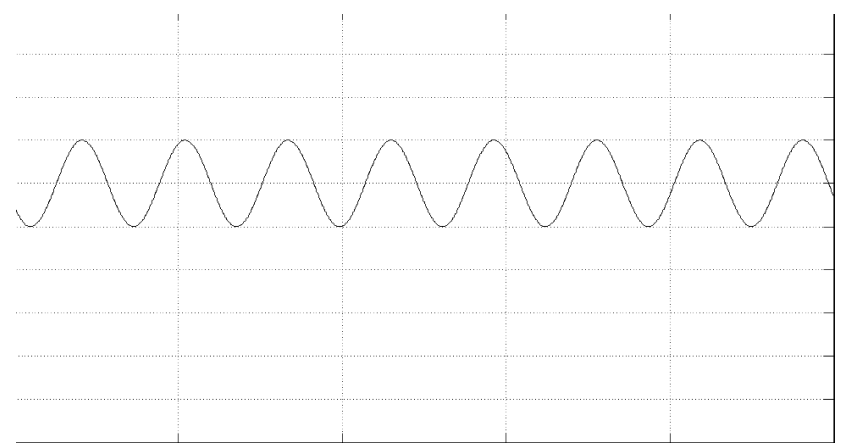

Рис. 8 - Результат розв'язання задачі нечіткого моделювання з ПІД регулятором, графік похибки Err

в процесі). Крок квантування $h=0.01$. Нечіткі регулятори налаштовані конкретно під модель і мають 74 правила, 3 вхідних величини по (5, 5, 3 терми кожна) і одна вихідна величина, яка має 5 термів. ПІД регулятор налаштований за допомогою функції TUNE, яка підібрала для нього оптимальні коефіціенти.

Висновки по отриманим графікам: основні параметри порівняння амплітуда, період та площа графіку процесу. Порівнюемо показання помилки (ERR).

1. Метод Мамдані. Амплітуда макс $=-3 \cdot 10^{18}, 0.8 \cdot 10^{18}$ перепад висот становить $3.8 \cdot 10^{18}$; період с 2,7 до 9,8 сек., тобто період регулювання становить 7,1 сек. Площа графріку - середня по величині з трьох методів, графік має коливальну форму, що сходиться.

2. Метод Сугено. Амплітуда макс $=-4.8 \cdot 10^{6}, 17.5 \cdot 10^{6}$ перепад висот становить $22.3 \cdot 10^{6}$; період с 2,75 до 10 сек., тобто період 
регулювання становить 7,25 сек. Площа графіку - найменша по величині з трьох методів, графік має коливальну форму, що сходиться.

3. ПІД регулятор. Амплітуда макс $=-1.7 \cdot 1^{015}, 1.7 \cdot 1^{015}$ перепад висот становить $3.4 \cdot 1^{015}$; період с 2,65 до 10 сек., тобто період регулювання становить 7,35 сек. Площа графріку - найбільша по величині з трьох методів, графік має фрорму синусоїди. Процес має форму автоколивального і не може закінчити процес регулювання.

На данному етапі аналізу отриманих результатів можна зробити висновок, що найбільш якісне регулювання дає нечіткий регулятор на основі методу Сугено.

4) Теплообмінник є типовим об'єктом управління з запізнюванням. Останне значно зменшує швидкодію системи і динамічну точність об'єкта управління. Передаточна функція такого об'єкта $W_{o}(s)=e^{-s T} G(s)$, де $G(s)$ - передаточна фрункція об'єкта без запізнення. Найбільш ефективним методом боротьби з запізненням є охвачування регулятора Р ланкою зворотного зв'язку з передаточною функцією $W_{o c}(s)=\left(1-e^{-s T}\right) G(s)$, яку називають предиктором (випереджувачем) Сміта.

5) Дослідження функцій приналежності у вигляді рівнобедреного трикутника, гаусових і трикутних, що перетинають весь діапазон зміни значень параметру показали, що найкращі перехідні характеристики при регулюванні досягаються при використанні трикутних, що перетинають весь діапазон.

\section{Список використаних джерел}

1. Белопухов А.К. Литье под давлением. - М.: Машиностроение, 1975. -397 c.

2. Литье под давлением / М.Б. Беккер, М.Л. Заславский, Ю.Ф. Игнатенко и др. - М.: Машиностроение , 1990. - 400 с.

3. Богушевський В.С. АСКТП комплексу лиття під тиском //Автоматизація виробничих процесів. - 2001. - № 2(13). - С. 53-55.

4. Хасмамедов Ф.И. Автоматизация управления трубчатими печами. - М.: Химия, 1980. - 216сc.

5. Гостев В.И., Маглюй С.А., Крайнев В.В. Оптимальные управляющие воздействия на объекты управления с форсирующими звеньями второго порядка // Электротехника и электроэнергетика. - 2002. - № 1. - С. 49-53.

6. Гостев В.И., Стеклов В.К. Системы автоматического управления с цифровыми регуляторами: Справочник. - К.: "Радиоаматор", 1998. - 704 c. 
7. Гостев В.И., Худолий Д.А., Баранов А.А. Синтез цифрових регуляторов систем автоматического управления. - К.: "Радиоаматор". - 2000. - 400 c.

8. Гостев В.И. Нечеткие регуляторы в системе автоматического управления. - К.: "Радіоаматор", 2008. - 972 с.

9. Богушевский В.С., Самарай Р.В. Система регулирования температуры пресс-формы на основе нечеткой логики // Металл и литье Украины - 2014. - № 3. - С. 16-20.

10. Богушевський В.С., Антоневич Я.К. Система керування машинами лиття під тиском // Наукові праці національного університету харчових технологій. - 2013. - № 48. - С. 10-16.

11. Кузьо І.В. Реалізація математичних моделей вертикальних коливань колісної машини засобами Matlab Simulink / I.B. Кузьо, О.В. Житенко, Г.В. Костельніцька // Автоматизація виробничих процесів у машинобудуванні та приладобудуванні. 2011. Вип. 45. - С.84-88.

Отримано 25.20.2015 p. 